\title{
SYNTHESIS, MOLECULAR STRUCTURE AND SPECTROSCOPIC AND COMPUTATIONAL STUDIES ON 4-(2-(2-(2-FORMYLPHENOXY)ETHOXY)ETHOXY)PHTHALONITRILE AS A FUNCTIONALIZED PHTHALONITRILE
}

\author{
Pınar Sen $^{1 *}$, Salih Zeki Yıldız ${ }^{2}$, Vildan Enisoglu Atalay ${ }^{3}$, Sibel Demir Kanmazalp ${ }^{4,5}$, Necmi Dege $^{6}$ \\ ${ }^{1}$ Centre for Nanotechnology Innovation, Department of Chemistry, Rhodes University, \\ PO Box 94, Grahamstown, 6140, South Africa \\ ${ }^{2}$ Sakarya University, Faculty of Arts and Sciences, Department of Chemistry, \\ 54187 Sakarya, Turkey \\ ${ }^{3}$ Uskudar University, Faculty of Engineering and Natural Sciences, Department of Bioengineering, \\ 34662 Istanbul, Turkey \\ ${ }^{4}$ Technical Sciences, Gaziantep University, Gaziantep, Turkey \\ ${ }^{5}$ Physics Department, Gebze Technical University, Kocaeli, Turkey \\ ${ }^{6}$ Ondokuz Mayls University, Faculty of Arts and Sciences, Department of Physics, \\ 55139 Samsun, Turkey \\ sen_pinar@hotmail.com
}

\begin{abstract}
This work presents the synthesis and characterization of a novel compound, 4-(2-(2-(2-formylphenoxy)ethoxy)ethoxy)phthalonitrile as the aldehyde functional group substituted as a phthalonitrile derivative. The spectroscopic properties of the compound were examined through Fourier-transform infrared spectroscopy, Proton nuclear magnetic resonance, Carbon nuclear magnetic resonance, Ultraviolet-visible spectroscopy, Mass spectrometry and elemental analyses. The molecular structure of the compound was also confirmed using X-ray single-crystal data with a theoretical comparative approach.
\end{abstract}

Keywords: single crystal; aldehyde; phthalonitrile; DFT; HOMO; LUMO

\section{СИНТЕЗА, МОЛЕКУЛСКА СТРУКТРУА И СПЕКТРОСКОПСКА И ПРЕСМЕТКОВНА СТУДИЈА \\ 3А 4-(2-(2-(2-ФОРМИЛФЕНОКСИ)ЕТОКСИ)ЕТОКСИ)ФТАЛОНИТРИЛ КАКО ФУНКЦИОНАЛИЗИРАН ФТАЛОНИТРИЛ}

Овој труд претставува синтеза и карактеризација на ново соединение, 4-(2-(2-(2формилфенокси)етокси)етокси)фталонитрил како алдехидна функционална група супституирана како фталонитрилен дериват. Спектроскопските својства на соединението беа истражени со Фуриеова трансформна инфрацрвена спектроскопија, протонска нуклеарна магнетна резонанција, јаглеродна нуклеарна магнетна резонанција, ултравиолетова - видлива спектроскопија, масена спектрометрија и елементна анализа. Молекулската структура на соединението беше потврдена и со употреба на рендгенска дифракција на монокристал преку теоретски компаративен пристап.

Клучни зборови: монокристал; алдехид; фталонитрил; DFT; HOMO; LUMO 


\section{INTRODUCTION}

Phthalonitrile derivatives are the most widely used precursors for the preparation of phthalocyanines, an important class of molecules [1]. In addition, phthalonitriles are used for the synthesis of high-performance polymers that display good mechanical properties and thermal stability [2].

A comprehensive understanding of phthalocyanine compounds continues to this day due to increasing interest on the $18-\pi$ electronic delocalization, thermal, photostability, coordination and optical properties. Their architectural flexibility also allows for the chemical and physical properties of these molecules to be regulated, which is an extraordinary feature for material science and allows these compounds to be used in many applications such as chemical sensors, photodynamic cancer therapy, liquid crystals, catalysis and non-linear optics [3-7].

The preparation of phthalocyanines is carried out via a cyclotetramerization reaction of phthalonitriles. The synthesis of phthalonitriles carrying functional groups leads to the formation of functionalized phthalocyanines. Phthalocyanines containing reactive groups have been a target of interest for chemists to switch to new molecular materials [8].

In this context, the development of aldehyde-substituted phthalocyanines from related phthalonitriles is crucial since they may carry out further chemical reactions on the macrocycle to prepare a Schiff base which is important for the development of coordination chemistry [9].

Using quantum chemistry and computation methodologies can elucidate atomic structures, charges and energetic information of the systems with an accuracy equivalent to or greater than those obtained experimentally. Therefore, theoretical calculations have been widely used as an effective tool for the intelligent design of new structures and for the investigation of the underlying structure-activity relationship.

In this study, the synthesis and characterization of 4-(2-(2-(2-formylphenoxy)ethoxy)ethoxy) phthalonitrile was performed to prepare an alternative starting material for the synthesis of different aldehyde substituted phthalocyanines. The x-ray crystallographic characterization of the second phthalonitrile derivative was performed as well as computational studies, which included geometry optimizations, HOMO and LUMO energies, determining molecular descriptors and NMR. These studies were performed with the DFT/B3LYP method in different solvents. The theoretical re- sults obtained from the computational studies were compared with experimental data.

\section{EXPERIMENTAL}

\subsection{Chemicals and instruments}

The following chemicals were obtained from Sigma-Aldrich; salicylaldehyde, 2-(2-chloroethoxy) ethanoethanol, acetonitrile, $\mathrm{K}_{2} \mathrm{CO}_{3}$, nitrophthalonitrile, dimethylformamide (DMF), hexane, chloroform $\left(\mathrm{CHCl}_{3}\right)$, methanol $(\mathrm{MeOH})$, ethanol $(\mathrm{EtOH})$ and diethylether. All other reagents and solvents were reagent grade quality and obtained from commercial suppliers. All solvents were stored over molecular sieves $(4 \AA)$ and subsequently dried and purified, as described by Perrin and Armarego [10]. An anaerobic, inert atmosphere was supplied by argon through a dual-bank vacuum-gas manifold system. Thin-Layer chromatography (TLC) was performed using silica gel 60-HF254 as an adsorbent. Column chromatography was performed with a silica gel (Merck grade 60) and size exclusion chromatography was conducted with a Bio-beads gel (SX-1). Melting points were determined using a Barnstad-Electrotermel 9200 apparatus and are uncorrected. Electronic spectra were recorded on a Shimadzu UV-2600 Pc-spectrophotometer with a $1 \mathrm{~cm}$ quartz cell. Infrared spectra were recorded on a Perkin Elmer Spectrum two FT-IR spectrophotometer equipped with Perkin Elmer UATR-TWO diamond ATR and corrected by applying the ATR-correction function of Perkin Elmer Spectrum software. The ${ }^{1} \mathrm{H}$ and ${ }^{13} \mathrm{C}$ NMR spectra were recorded with a Varian Mercury Plus $300 \mathrm{MHz}$ spectrometer. Mass analysis was measured on a Micro-Mass Quatro LC/ULTIMA LCMS/MS spectrometer. The elemental composition of the sample was analyzed with an element analyser (Flash 2000, Thermo Scientific).

\subsection{X-ray crystallography}

A suitable single crystal of the title compound was mounted on goniometer and data were collected at a STOE IPDS II (2 image plate detector) using a graphite monochromated $\mathrm{MoK} \alpha$ radiation $(\lambda=0.71073 \AA)$. Cell parameters of the compound were determined with WinGX software [11]. The structure of the titled compound was solved by the direct methods procedure in the SHELXS-97 program [12]; all the non-hydrogen atoms were refined anisotropically using the SHELXL-2014/7 program [13]. 
The molecular figures were prepared with the help of Mercury and ORTEP-3 program packages $[14,15]$. All geometrical calculations were carried out using the program PLATON [16]. All non-hydrogen atoms were fixed geometrically. Selected crystallographic and refinement results for the compound are presented in Table 1.

CCDC 1585050 contains supplementary crystallographic data (excluding structure factors) for the compounds reported in this article. These data can be obtained free of charge via http://www.ccdc.cam.ac.uk/deposit [or from the Cambridge Crystallographic Data Centre (CCDC), 12 Union Road, Cambridge CB2 1EZ, UK; fax: +44(0)1223 336033; e-mail: deposit@ccdc.cam. ac.uk].

Table 1

Crystallographic data and refinement parameters for the compound, $\mathrm{C}_{18} \mathrm{H}_{18} \mathrm{C}_{14} \mathrm{~N}_{4} \mathrm{O}_{4} \mathrm{~S}_{2}$

\begin{tabular}{|c|c|}
\hline \multicolumn{2}{|l|}{ Crystal data } \\
\hline Chemical formula & $\mathrm{C}_{19} \mathrm{H}_{16} \mathrm{~N}_{2} \mathrm{O}_{4}$ \\
\hline $\mathrm{Mr}$ & 336.34 \\
\hline Crystal system, space group & Monoclinic, $P 2_{1} / c$ \\
\hline Temperature (K) & 296 \\
\hline $\mathrm{a}, \mathrm{b}, \mathrm{c}(\AA)$ & $13.6125(12), 15.9430(15), 8.4237$ (7) \\
\hline$\beta\left(^{\circ}\right)$ & $107.059(6)$ \\
\hline $\mathrm{V}\left(\AA^{3}\right)$ & $1747.7(3)$ \\
\hline $\mathrm{Z}$ & 4 \\
\hline Radiation type & Mo $K \alpha$ \\
\hline$\mu\left(\mathrm{mm}^{-1}\right)$ & 0.09 \\
\hline Crystal size (mm) & $0.75 \times 0.32 \times 0.09$ \\
\hline \multicolumn{2}{|l|}{ Data collection } \\
\hline Diffractometer & STOE IPDS 2 diffractometer \\
\hline Absorption correction & Integration \\
\hline Tmin, Tmax & $0.600,0.790$ \\
\hline No. of measured, independent and observed $[\mathrm{I}>2 \sigma(\mathrm{I})]$ reflections & $13779,3252,1352$ \\
\hline Rint & 0.129 \\
\hline$(\sin \theta / \lambda) \max (\AA-1)$ & 0.606 \\
\hline \multicolumn{2}{|l|}{ Refinement } \\
\hline$R\left[F^{2}>2 \sigma\left(F^{2}\right)\right], w R\left(F^{2}\right), S$ & $0.085,0.195,1.01$ \\
\hline $\mathrm{H}$-atom treatment & $\mathrm{H}$-atom parameters constrained \\
\hline$\Delta \rho_{\max }, \Delta \rho_{\min }\left(\mathrm{e} \AA^{-3}\right)$ & $0.18,-0.19$ \\
\hline
\end{tabular}

\subsection{Computational methods}

A conformational search to determine the stable structure of synthesized compound was performed with a semi-empirical PM6 method [17] using the program Spartan'16 v1.1.4 [18]. The obtained most stable conformer structure was optimized with a semi-empirical PM6 method and the Density Functional Theory (DFT) B3LYP (Becke's Three Parameter Hybrid Functional using the Lee, Yang and Parr Correlation Functional) [19] with the $6-311++G(d, p)$ method in the gas and DMF phases with the IEF-PCM approach [20]. The $\mathrm{E}_{\mathrm{HO}}$ мо-E $\mathrm{E}_{\text {LUMO }}$ were calculated using time-dependent density functional theory (TD-DFT) at the B3LYP/6-311+G(d,p) levels in DMF phase, which was done by using the Self-Consistent Reaction Field (SCRF) method. The calculation of nuclear magnetic resonance (NMR) shielding tensors with the Gauge-Independent Atomic Orbital (GIAO) [21] method was computed with same basis set for the synthesized compound when gas, $\mathrm{CDCl}_{3}$ or dDMSO were used as a solvent. At the same time molecular descriptors such as electronegativity $(\chi)$, electron affinity $(A)$, hardness $(\eta)$, softness $(S)$, electrophilicity index $(\omega)$ must be defined by the same computational methods. There is a practical calculation method to calculate for chemical hard- 
ness $(\eta)$ and electronegativity $(\chi)($ Eq. 1$)$, as given by Parr and Pearson [22].

$$
\eta \approx \frac{I-A}{2}, \quad x \approx \frac{I+A}{2}
$$

where $I$ is the ionization potential and $A$ is the electron affinity. The Koopman's theorem was used for the calculation of $I$ and $A$ values derived from the frontier orbital energies of optimized neutral molecules, according to this theorem $I=-\mathrm{E}_{\mathrm{HOMO}}$ and $A$ $=-E_{\text {LUMO }}$. Using Koopman's theorem, the chemical hardness and electronegativity are defined in terms of orbital energies (Eq. 2):

$$
\begin{gathered}
\eta \approx \frac{\mathrm{E}(\text { LUMO })-\mathrm{E}(\text { HOMO })}{2}, \\
x=-\mu \approx \frac{-\mathrm{E}(\text { LUMO })-\mathrm{E}(\text { HOMO })}{2}
\end{gathered}
$$

The $\omega$ and $S$ values are calculated by the following Eq. 3:

$$
\omega \approx \mu^{2} / 2 \eta, S \approx \frac{1}{(2 \eta)}
$$

All visualizations and calculations were carried out with the methods implemented in GaussView5.0 [23] and Gaussian 09 package [24].

\subsection{Synthesis}

\subsubsection{2-(2-(2-hydroxyethoxy)ethoxy)benzaldehyde (1)}

The preparation of $\mathbf{1}$ was carried out by reaction of salicylaldehyde and 2-(2-chloroethoxy)ethanol according to the published literature [25]. The spectral data of $\mathbf{1}$ are in accordance with the published structure.

\subsubsection{4-(2-(2-(2-formylphenoxy)ethoxy)ethoxy) phthalonitrile (2)}

4-Nitrophthalonitrile $(0.5 \mathrm{~g}, 2.9 \mathrm{mmol})$ and 2-(2-(2-hydroxyethoxy)ethoxy)benzaldehyde
(0.61 g; $2.9 \mathrm{mmol}$ ) were dissolved in N,N- dimethylformamide $(15 \mathrm{ml})$, dissolved and degassed by argon in a dual-bank vacuum-gas manifold system. After stirring for 15 minutes, finely ground anhydrous potassium carbonate $(1 \mathrm{~g}, 7.2 \mathrm{mmol})$ was added portion-wise over two hours with efficient stirring. The suspension solution was maintained at $60{ }^{\circ} \mathrm{C}$ for 24 hours. The progress of the reaction was monitored by TLC using $\mathrm{CHCl}_{3} / \mathrm{Hexane}(5 / 1)$ solvent system. When the reaction was completed, the crude product was precipitated by pouring it into ice water $(100 \mathrm{ml})$. The water phase was extracted with diethylether $(3 \times 25 \mathrm{ml})$ and the combined organic extracts were washed with water and dried over $\mathrm{Na}_{2} \mathrm{SO}_{4}$. The product was then purified with column chromatography on a silica-gel and eluting with a $\mathrm{CHCl}_{3} / \mathrm{Hexane}(5 / 1)$ solvent system to yield (2) as white solid (yield $=92 \%(0.89 \mathrm{~g})$ ). FT-IR (UATR-TWO ${ }^{\mathrm{TM}}$ ) $v \max / \mathrm{cm}^{-1}: 3078$ (Ar, CH), 2935-2873 (Aliph., C-H), $2720(\mathrm{O}=\mathrm{C}-\mathrm{H}), 2229$ $(-\mathrm{C} \equiv \mathrm{N}), 1681(-\mathrm{C}=\mathrm{O}), 1597(\mathrm{C}=\mathrm{C}), 1485,1454(\mathrm{C}-$ C), 1286 (Asym., Ar-O-), 1242 (C-O-C), 1161 (Sym., Ar-O-), 1134, 1097, 1043, 831, 759. ${ }^{1} \mathrm{H}-$ NMR (DMSO) $\delta(\mathrm{ppm}): 10.34(\mathrm{~s}, 1 \mathrm{H}), 8.24(\mathrm{~d}$, 1H), 8.01-8.06 (m, 2H), 7.74-7.66 (m, 1H), 7.45 $(\mathrm{d}, 1 \mathrm{H}), 7.23(\mathrm{~d}, 1 \mathrm{H}), 7.05-7.11(\mathrm{~m}, 1 \mathrm{H}), 4.30(\mathrm{t}$, $4 \mathrm{H}), 3.88(\mathrm{t}, 4 \mathrm{H}) .{ }^{13} \mathrm{C}-\mathrm{NMR}\left(\mathrm{CDCl}_{3}\right) \delta(\mathrm{ppm})$ : $190.64,162.51,159.12,137.28,128.12,125.44$, $124.99,121.57,120.92,120.75,117.78,116.91$, 116.42, 114.62, 111.27, 69.41, 68.96. MS (ESI): $\mathrm{m} / \mathrm{z} 338.25[\mathrm{M}+1]^{+}, 372.23\left[\mathrm{M}+2 \mathrm{H}_{2} \mathrm{O}\right]^{+}, 322.23$ $[\mathrm{M}-\mathrm{CHO}]^{+}$

Anal. Calc. for $\mathrm{C}_{19} \mathrm{H}_{16} \mathrm{~N}_{2} \mathrm{O}_{4}$ (\%): C, 67.85; H, 4.79; N, 8.33; O, 19.03; Found (\%): C, 67.68; $\mathrm{H}, 4.81 ; \mathrm{N}, 8.30$.

\section{RESULTS AND DISCUSSION}

\subsection{Synthesis and spectroscopic characterization}

Scheme 1 shows the synthetic route for target compound 2 .

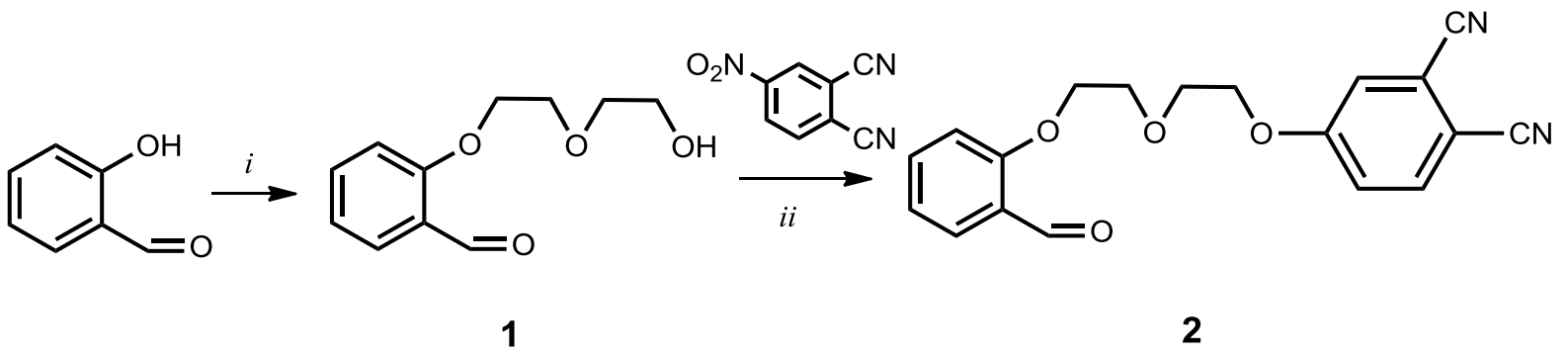

Scheme 1. Synthesis route: (i) 2-(2-chloroethoxy)ethanol, $\mathrm{K}_{2} \mathrm{CO}_{3},(\mathbf{1}), \mathrm{CH}_{3} \mathrm{CN}$, reflux (ii) $\mathrm{DMF}, \mathrm{K}_{2} \mathrm{CO}_{3}$, 4-nitrophthalonitrile, $60{ }^{\circ} \mathrm{C}$ 
As a first step, 2-(2-(2-hydroxyethoxy)ethoxy)benzaldehyde (1) was prepared by reacting of commercially available salicylaldehyde with 2-(2chloroethoxy)ethanol in acetonitrile in the presence of $\mathrm{K}_{2} \mathrm{CO}_{3}$ using an established procedure [25]. The compound 4-(2-(2-(2-formylphenoxy)ethoxy)ethoxy)phthalonitrile (2) was obtained as a white powder from the reaction of 2-(2-(2-hydroxyethoxy)ethoxy)benzaldehyde (1) and 4-nitrophthalonitrile, using $\mathrm{K}_{2} \mathrm{CO}_{3}$ as a catalyst in DMF through stirring at $60{ }^{\circ} \mathrm{C}$ for 24 hours. The purification of $\mathbf{2}$ was performed by column chromatography (silica gel, eluent: $\mathrm{CHCl}_{3} / \mathrm{Hexane}-5 / 1$ ), resulting in $92 \%$ yield. A suitable crystal of molecule 2 was isolated for $x$-ray analysis upon crystallization from a $\mathrm{CHCl}_{3} /$ methanol solution.

The characterization of product (2) was carried out through combination of methods in- cluding FT-IR, ${ }^{1} \mathrm{H}-\mathrm{NMR},{ }^{13} \mathrm{C}-\mathrm{NMR}$, mass spectroscopy and elemental analysis. All the spectral data are in accordance with the proposed structure. More specifically, when comparing the FT-IR spectra of 1 and 2, the disappearance of $-\mathrm{OH}$ vibration at $3399 \mathrm{~cm}^{-1}$ and the appearance of new absorption bands at $2229 \mathrm{~cm}^{-1}$ clearly indicated the formation of 2 . The peak attributed to the $-\mathrm{C}=\mathrm{O}$ stretching was observed at $1657 \mathrm{~cm}^{-1}$ in the FT-IR spectra of compound $\mathbf{1}$, but shifted to $1681 \mathrm{~cm}^{-1}$ in the FT-IR spectrum of compound 2. In addition, the typical aliphatic $-\mathrm{C}-\mathrm{H}$ vibrational bands at 2935-2873 $\mathrm{cm}^{-1}$ were assigned to $-\mathrm{C}-\mathrm{H}$ stretching of the ethylene groups of compound 2 . The other sharp peaks at $1286 \mathrm{~cm}^{-1}, 1242 \mathrm{~cm}^{-1}, 1161 \mathrm{~cm}^{-1}$ and $1134 \mathrm{~cm}^{-1}$ were attributed to asym. Ar-O-, CO-C, sym. Ar-O- and sym. Ar-O- stretching bands, respectively (Fig. 1).

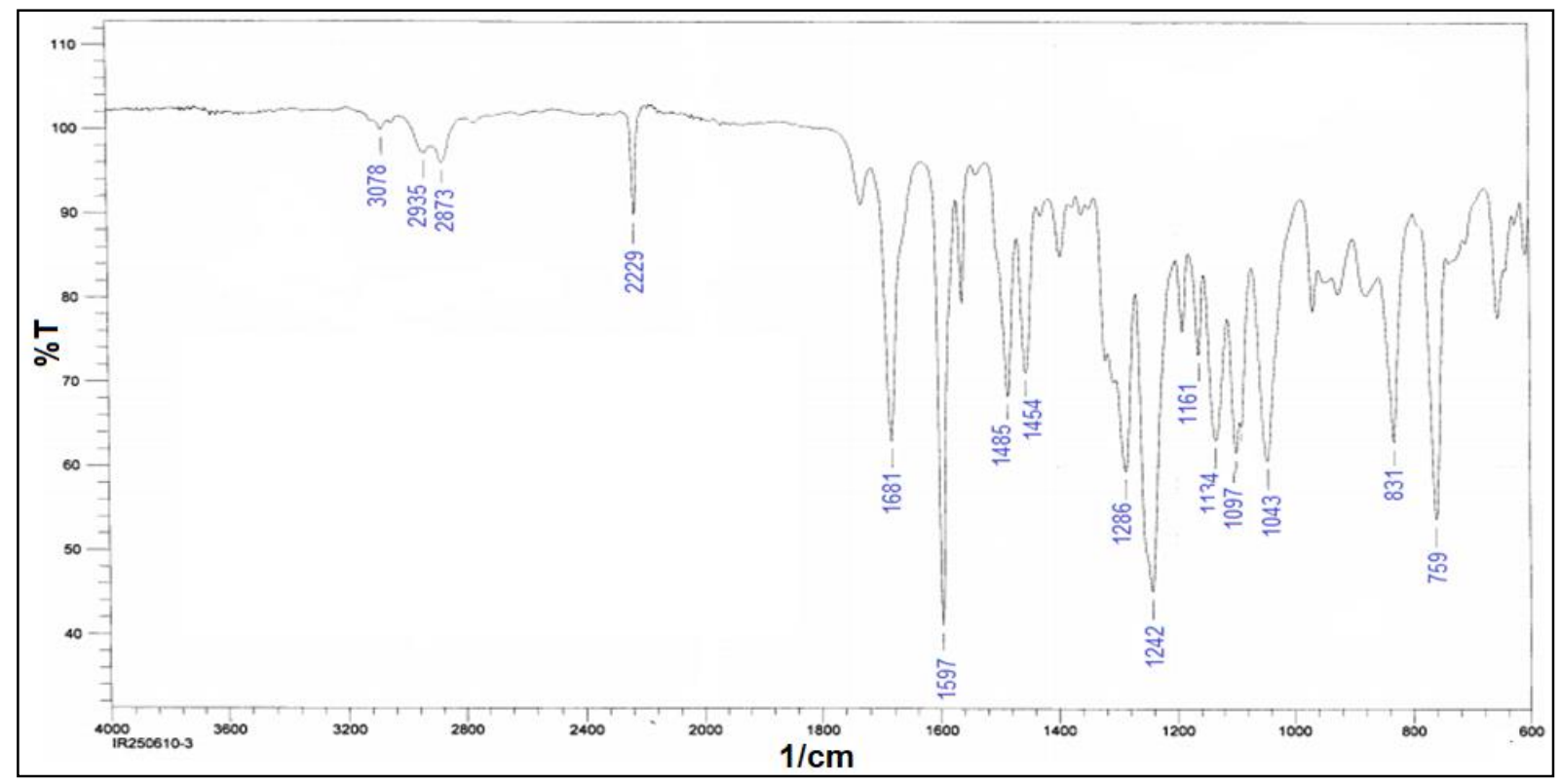

Figure 1. FT-IR spectrum of compound 2

The ${ }^{1} \mathrm{H}-\mathrm{NMR}$ data provided satisfactory information about the proposed structure of the target compound (2). When comparing the ${ }^{1} \mathrm{H}-\mathrm{NMR}$ spectra of compound $\mathbf{1}$ and $\mathbf{2}$, the disappearances of the $\mathrm{OH}$ proton signal of 2-(2-(2-hydroxyethoxy)ethoxy)benzaldehyde (1) in the ${ }^{1} \mathrm{H}-\mathrm{NMR}$ spectra in compound $\mathbf{2}$ and the appearance of new peaks in aromatic region at $8.24 \mathrm{ppm}, 7.45 \mathrm{ppm}$, $7.23 \mathrm{ppm}$ arising from phthalonitrile unit are evidence of the substitution of the phthalonitrile derivative 2 (Fig. 2). Aliphatic peaks belonging to ethylene chains were observed at $4.30 \mathrm{ppm}$ and $3.88 \mathrm{ppm}$ as a triplet; these peaks were expected results. The other aromatic peaks where the alde- hyde is present were seen at 7.74-7.66 ppm, 7.45 ppm and 7.11-7.05 ppm. The characteristic aldehyde proton was detected as a singlet at 10.34 ppm.

In the ${ }^{13} \mathrm{C}-\mathrm{NMR}$ spectrum of compound 2 (Fig. 3), the presence of the signal at $116.91 \mathrm{ppm}$ and $116.42 \mathrm{ppm}$ attributed to the nitrile carbon atoms are distinct differences from compound $\mathbf{1}$. The aromatic carbon atoms peaks were appeared at between $162.51 \mathrm{ppm}$ and $114.62 \mathrm{ppm}$. The aliphatic carbon peaks linking two aromatic rings emerged at $69.41 \mathrm{ppm}$ and $68.96 \mathrm{ppm}$. The theoretical ${ }^{1} \mathrm{H}$ and ${ }^{13} \mathrm{C}$ chemical shift values of the title compound are comparative with the experimental ones (Table 2). 


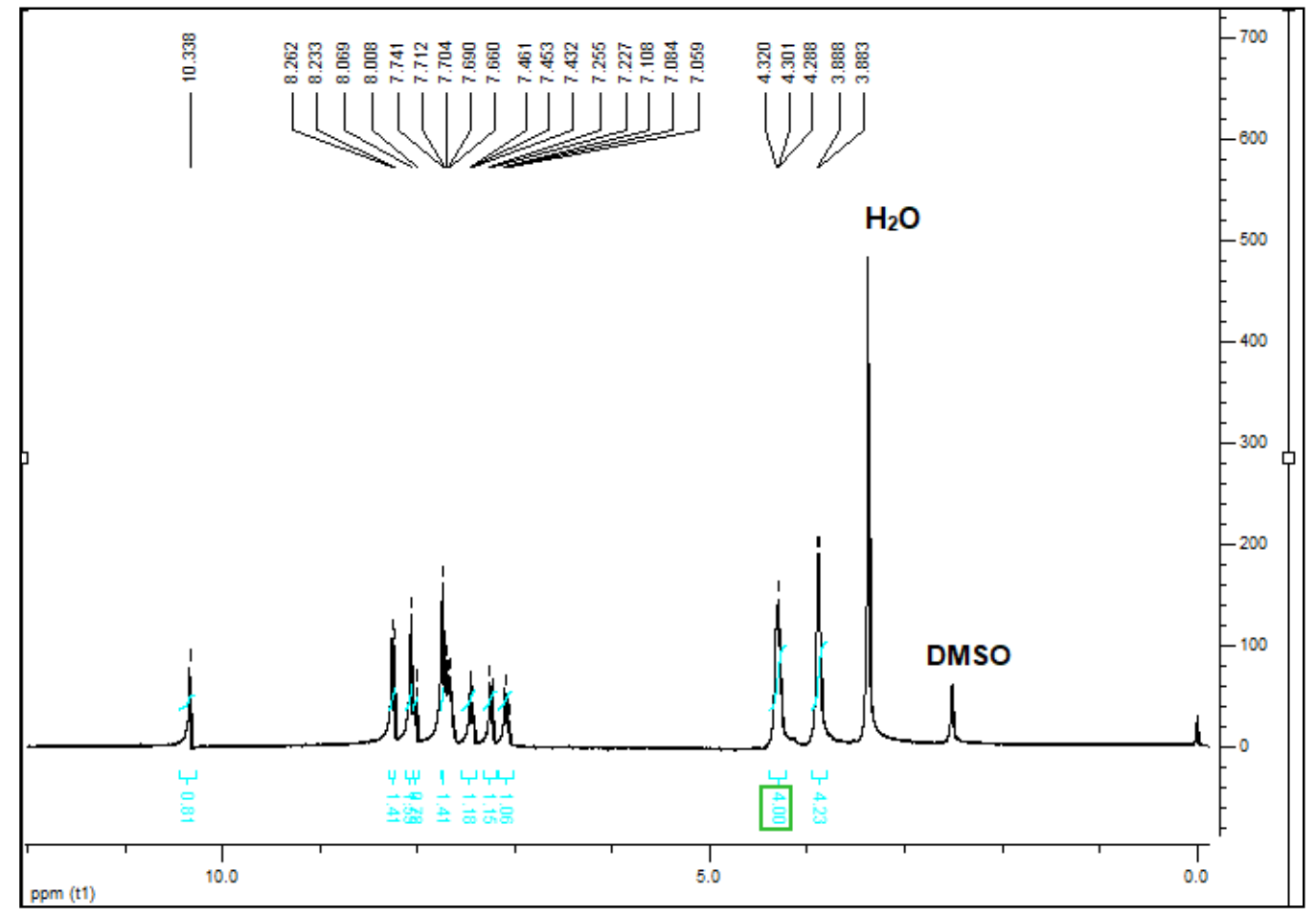

Figure 2. ${ }^{1} \mathrm{H}-\mathrm{NMR}$ spectrum of compound 2

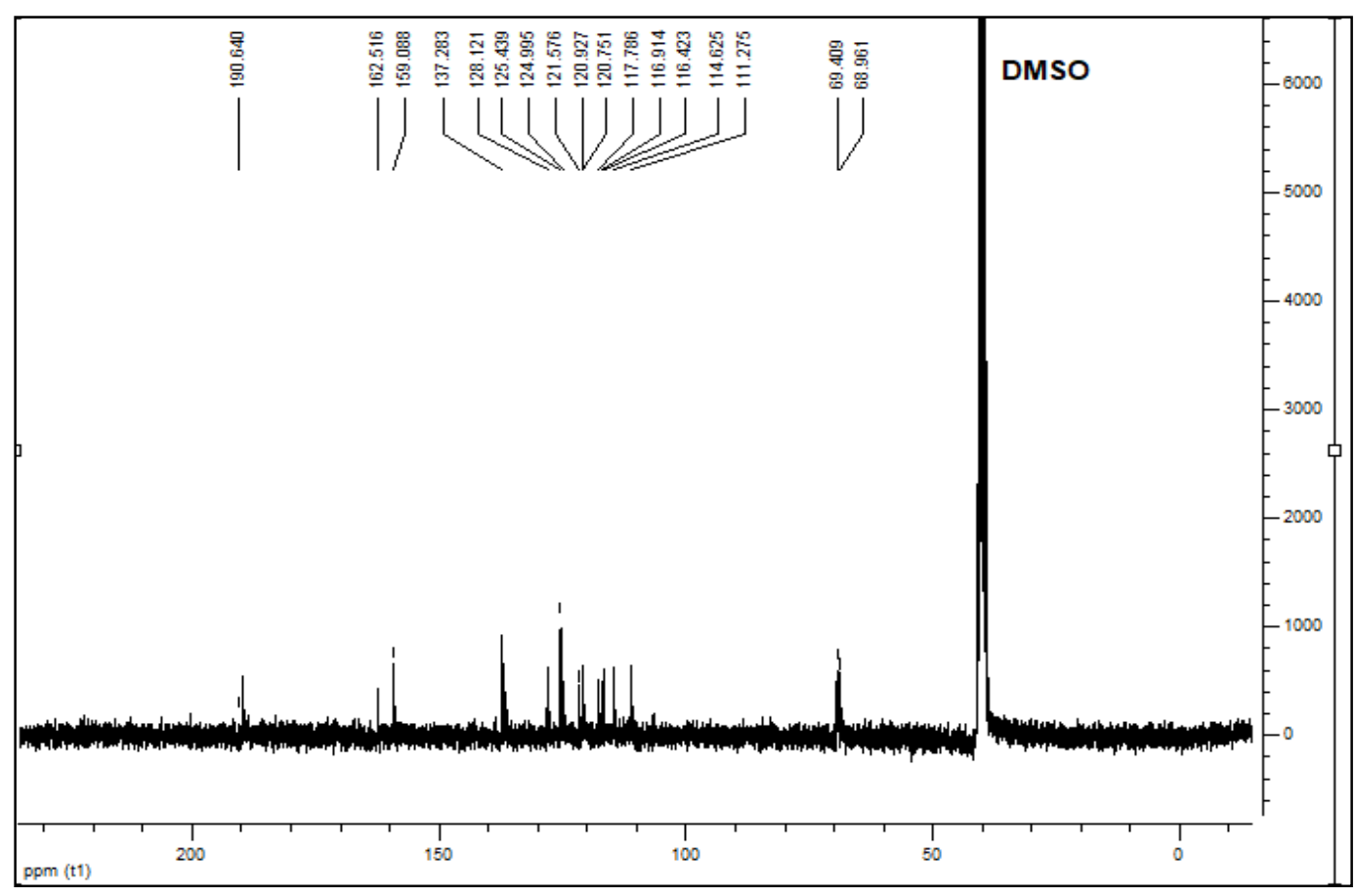

Figure 3. ${ }^{13} \mathrm{C}-\mathrm{NMR}$ spectrum of compound $\mathbf{2}$ 
The mass spectrum of compound $\mathbf{2}$ was obtained by the LC-MS/MS spectrometer, thus confirming the proposed structure. In the mass spectrum of $\mathbf{2}$, the presence of molecular ion peak $(\mathrm{m} / \mathrm{z}$ : $\left.338.25[\mathrm{M}+1]^{+}\right)$indicates the formation of desired product. Apart from the 2 moles of $\mathrm{H}_{2} \mathrm{O}$, there was an adducted ion peak at m/z: $372.23\left[\mathrm{M}+2 \mathrm{H}_{2} \mathrm{O}\right]^{+}$ and the fragment ion peak at $322.23[\mathrm{M}-\mathrm{CHO}]^{+}$in the mass spectrum (Fig. 4)

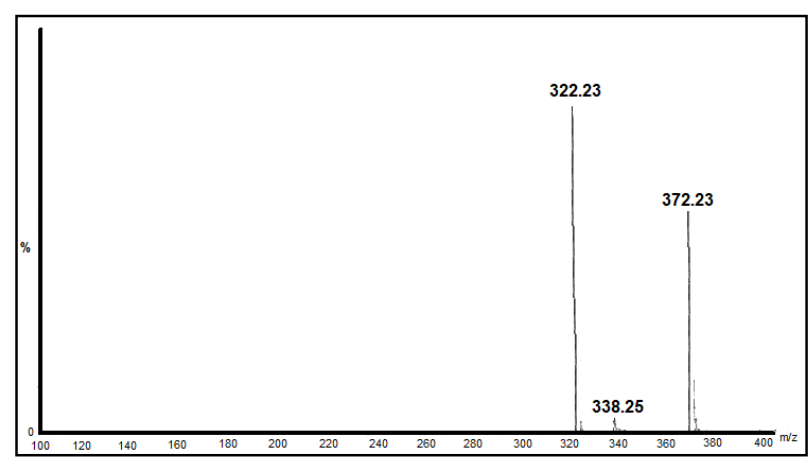

Figure 4. Mass spectrum of 2.

Ta ble 2

Theoretical (according to the calculations of B3LYP/6-311+G(d,p) in different solvents) and experimental ${ }^{13} \mathrm{C}$ and ${ }^{1} \mathrm{H}$ isotropic chemical shifts with respect to TMS. All values are given in ppm.

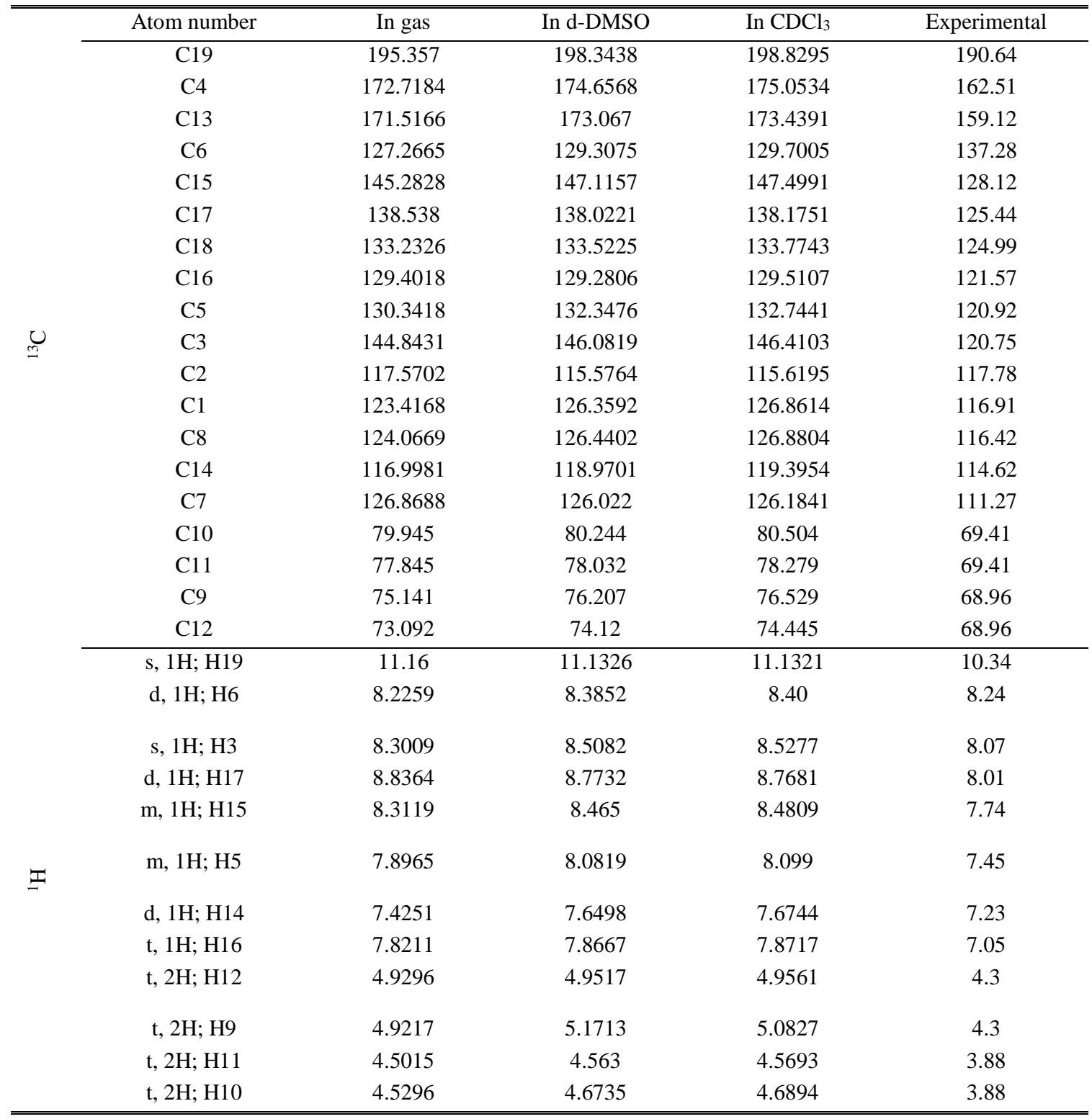




\subsection{Crystal structure description of the compound}

The compound crystallizes in the monoclinic space group $P 2_{1} / c$ with one molecule in the asymmetric unit. The single crystal X-ray structure is shown in Figure 5. In the title compound, the phthalonitrile ring and the formylphenoxy ring are non-planar, while the dihedral angle between the two rings is $79.4(1)^{\circ}$.

The selected geometric parameters (Table 3) at oxygen and nitrogen atoms also show substantial variations from threefold symmetry. The similarity of the $\mathrm{C}-\mathrm{O}$ bond lengths, apart from the $\mathrm{C} 19-$ $\mathrm{O} 4$ bond length, indicates localized bonding arrangements rather than delocalized bonds. The O4- $\mathrm{C} 19-\mathrm{C} 18$ angle around the carbonyl carbon of the aldehyde group is $122.5(6)^{\circ}$. At the same time, this angle was calculated with the theoretical method, which reported the $\mathrm{O}-\mathrm{C}-\mathrm{C}$ angle as $124.886^{\circ}$ and $-124.906^{\circ}$ in gas and DMF phases, respectively.

The conformation about the two cyano groups $\mathrm{C} 1-\mathrm{N} 1$ and $\mathrm{C} 8-\mathrm{N} 2$ bonds are 1.141(6) and 1.140(7) $\AA$ (where the $\mathrm{N} 1-\mathrm{C} 1-\mathrm{C} 2$ and $\mathrm{N} 2-$ C8 - C7 dihedral angle is 179.0(6) and 178.4(6), respectively (Table 3 ). These lengths follow literature values [26]. The optimized geometric structure with DFT/B3LYP/6-311++G(d,p) method in the gas and DMF phases is also compared with the experimental values in Table 3. These $\mathrm{C} 1-\mathrm{N} 1$ and C8 - N2 bonds lengths are computed 1.15505 and $1.15561 \AA$ in gas and 1.5523 and $1.15621 \AA$ in DMF phase, respectively. Furthermore, the N1$\mathrm{C} 1-\mathrm{C} 2$ and $\mathrm{N} 2-\mathrm{C} 8-\mathrm{C} 7$ dihedral angles are calculated 177.890 and $178.628^{\circ}$ in gas and 178.939 and $179.101^{\circ}$ in DMF phase, respectively. The obtained values in the solvent phase overlap more according to the gas phase.

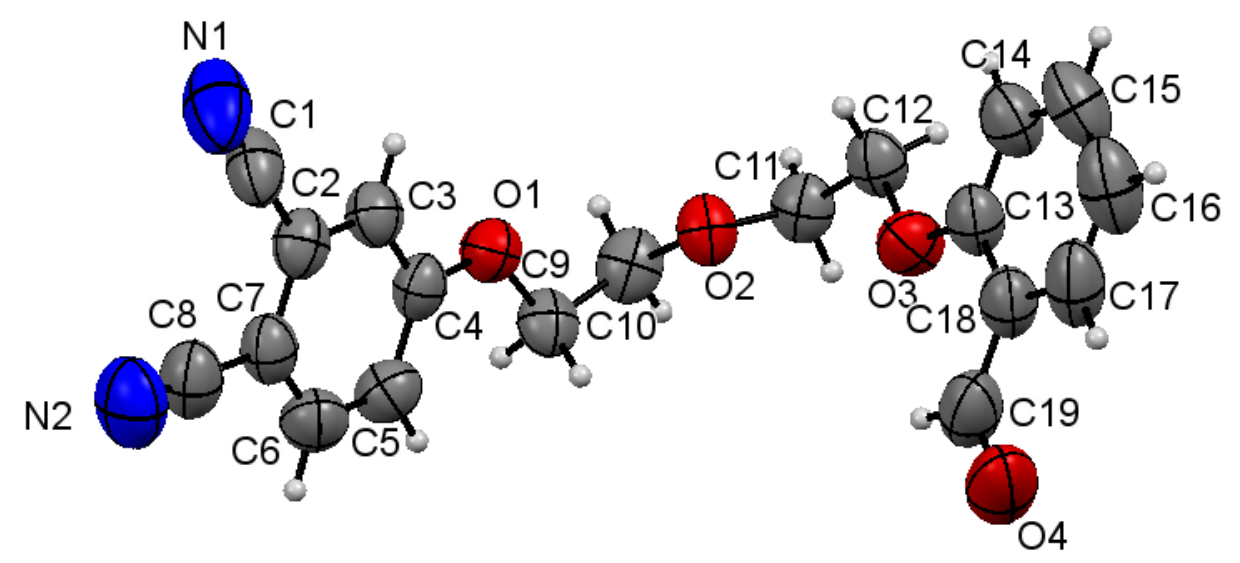

(a)

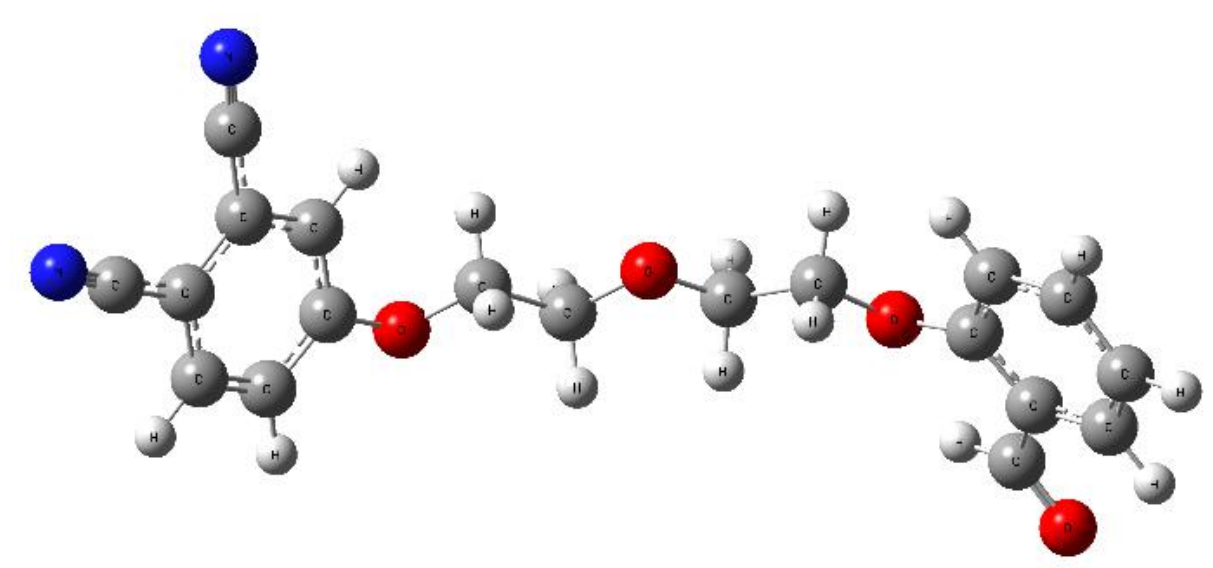

(b)

Figure 5. (a) The molecular structure of the $\mathrm{C}_{19} \mathrm{H}_{16} \mathrm{~N}_{2} \mathrm{O}_{4}$ with the displacement ellipsoids of non-hydrogen atoms drawn at the $30 \%$ probability level. (b) Optimized structure of the title compound 
Ta b le 3

Selected bond lengths (A) and angles $\left({ }^{\circ}\right)$ for $\mathrm{C}_{19} \mathrm{H}_{16} \mathrm{~N}_{2} \mathrm{O}_{4}$ structure.

These data include those obtained experimentally and those calculated with the DFT/B3LYP/6-311++G(d,p) method in both gas and DMF phases

\begin{tabular}{|c|c|c|c|}
\hline & \multirow{2}{*}{ Exp } & \multicolumn{2}{|c|}{ Calculated } \\
\hline & & In gas & In DMF \\
\hline \multicolumn{4}{|l|}{ Bond lengths (Å) } \\
\hline $\mathrm{O} 2-\mathrm{C} 10$ & $1.414(5)$ & 1.41523 & 1.41824 \\
\hline $\mathrm{O} 2-\mathrm{C} 11$ & $1.416(5)$ & 1.41931 & 1.42122 \\
\hline $\mathrm{O} 1-\mathrm{C} 4$ & $1.346(5)$ & 1.35697 & 1.35117 \\
\hline $\mathrm{O} 1-\mathrm{C} 9$ & $1.432(5)$ & 1.43439 & 1.44090 \\
\hline $\mathrm{O} 3-\mathrm{C} 13$ & $1.352(6)$ & 1.36243 & 1.35733 \\
\hline $\mathrm{O} 3-\mathrm{C} 12$ & $1.426(5)$ & 1.42580 & 1.43249 \\
\hline $\mathrm{O} 4-\mathrm{C} 19$ & $1.226(6)$ & 1.21533 & 1.22016 \\
\hline $\mathrm{C} 1-\mathrm{N} 1$ & $1.141(6)$ & 1.15505 & 1.5523 \\
\hline $\mathrm{C} 8-\mathrm{N} 2$ & $1.140(7)$ & 1.15561 & 1.15621 \\
\hline \multicolumn{4}{|l|}{ Bond angles $\left({ }^{\circ}\right)$} \\
\hline $\mathrm{C} 10-\mathrm{O} 2-\mathrm{C} 11$ & $112.1(3)$ & 114.548 & 113.519 \\
\hline $\mathrm{C} 4-\mathrm{O} 1-\mathrm{C} 9$ & $119.3(4)$ & 121.749 & 119.635 \\
\hline $\mathrm{C} 13-\mathrm{O} 3-\mathrm{C} 12$ & $119.4(4)$ & 119.867 & 119.742 \\
\hline $\mathrm{O} 1-\mathrm{C} 4-\mathrm{C} 3$ & $116.3(5)$ & 124.886 & 124.906 \\
\hline $\mathrm{N} 1-\mathrm{C} 1-\mathrm{C} 2$ & $179.0(6)$ & 177.890 & 178.939 \\
\hline $\mathrm{N} 2-\mathrm{C} 8-\mathrm{C} 7$ & $178.4(6)$ & 178.628 & 179.101 \\
\hline $\mathrm{O} 4-\mathrm{C} 19-\mathrm{C} 18$ & $122.5(6)$ & 124.886 & 124.906 \\
\hline \multicolumn{4}{|l|}{ Torsion angles $\left({ }^{\circ}\right)$} \\
\hline $\mathrm{C} 4-\mathrm{O} 1-\mathrm{C} 9-\mathrm{C} 10$ & $-173.2(4)$ & 96.523 & 97.656 \\
\hline $\mathrm{C} 12-\mathrm{O} 3-\mathrm{C} 13-\mathrm{C} 14$ & $1.2(7)$ & -4.198 & -1.24 \\
\hline $\mathrm{O} 3-\mathrm{C} 12-\mathrm{C} 11-\mathrm{O} 2$ & $71.9(5)$ & 72.452 & 71.732 \\
\hline $\mathrm{O} 1-\mathrm{C} 9-\mathrm{C} 10-\mathrm{O} 2$ & $68.9(5)$ & 71.750 & 70.756 \\
\hline $\mathrm{C} 10-\mathrm{O} 2-\mathrm{C} 11-\mathrm{C} 12$ & $175.3(4)$ & 165.865 & 170.314 \\
\hline $\mathrm{C} 13-\mathrm{C} 18-\mathrm{C} 19-\mathrm{O} 4$ & $176.3(5)$ & 179.696 & 179.329 \\
\hline
\end{tabular}

In the crystal, hydrogen-bonding and Van der-Waals interactions are dominant. The $\mathrm{H}$ atoms in the phthalonitrile ring form intermolecular $\mathrm{C}-$ $\mathrm{H} . . . \mathrm{N}$ and $\mathrm{C}-\mathrm{H} \ldots \mathrm{O}$ interactions, linking molecules to form chains (Figure 6b). Intermolecular $\mathrm{C}-\mathrm{H} . . . \pi$ interactions support hydrogen bond geometry. An interaction occurred between the centre of the $\mathrm{Cg}(2)$ ring identified with $\mathrm{C} 13-\mathrm{C} 18$ and the
$\mathrm{H} 12 \mathrm{a}$ atom bonded to the $\mathrm{C} 12$ atom [C12$\mathrm{H} 12 \mathrm{a} . . . \mathrm{Cg}(2)^{\mathrm{iii}}$; symmetry code; (iii) $\left.\mathrm{x}, 1 / 2-\mathrm{y}, 1 / 2+\mathrm{z}\right]$. Furthermore, the $\pi-\pi$ stacking interactions between the phthalonitrile rings with a centroid-centroid $[\mathrm{Cg}(1)-\mathrm{Cg}(1)]$ distance of $3.592 \AA[\mathrm{Cg}(1)$ are the centroid of the $\mathrm{C} 2-\mathrm{C} 7$ ring (symmetry code: $-\mathrm{x}, 1-$ $\mathrm{y}, 1-\mathrm{z})]$. The detailed geometric parameters of the hydrogen bonds are given in Table 4 .

T a ble 4

Hydrogen-bond geometries $\left(A,{ }^{\circ}\right)$ for $\mathrm{C}_{19} \mathrm{H}_{16} \mathrm{~N}_{2} \mathrm{O}_{4}$

\begin{tabular}{|c|c|c|c|c|}
\hline & $\overline{D-H} \cdots A$ & H $\cdots A$ & $\bar{D} \cdots \boldsymbol{A}$ & $D-\mathbf{H} \cdots A$ \\
\hline $\mathrm{C} 19-\mathrm{H} 19 \cdots \mathrm{O} 3$ & 0.93 & 2.42 & $2.740(7)$ & 100 \\
\hline $\mathrm{C} 3-\mathrm{H} 3 \cdots \mathrm{O} 4^{\mathrm{i}}$ & 0.93 & 2.454 & 3.336 & 158 \\
\hline $\mathrm{C} 5-\mathrm{H} 5 \cdots \mathrm{N} 1^{\mathrm{ii}}$ & 0.93 & 2.586 & 3.348 & 140 \\
\hline $\mathrm{C} 12-\mathrm{H} 12 \mathrm{a} \cdots \mathrm{Cg}(2)^{\mathrm{iii}}$ & 0.97 & 2.75 & 3.56 & 142 \\
\hline
\end{tabular}




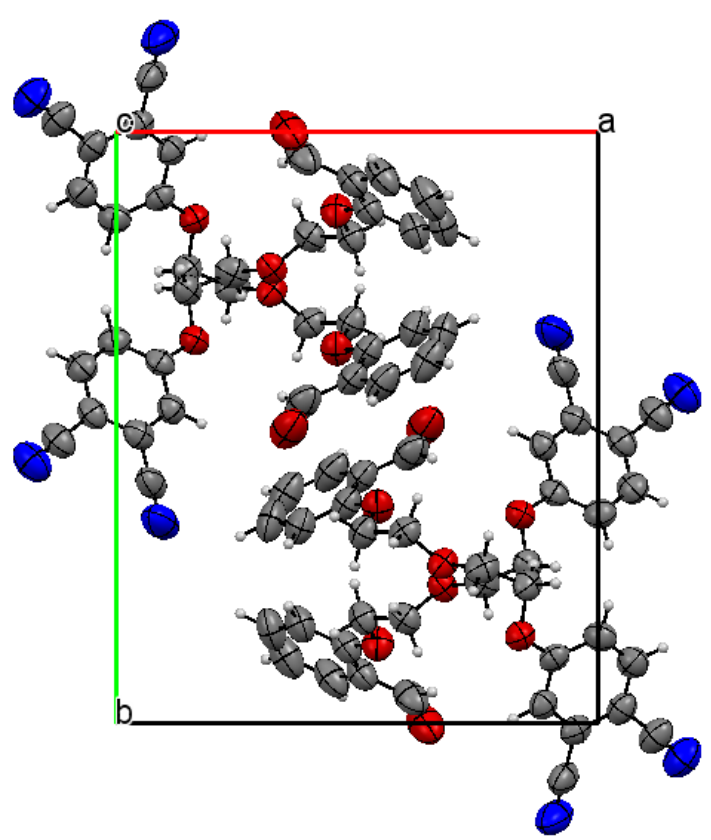

(a)

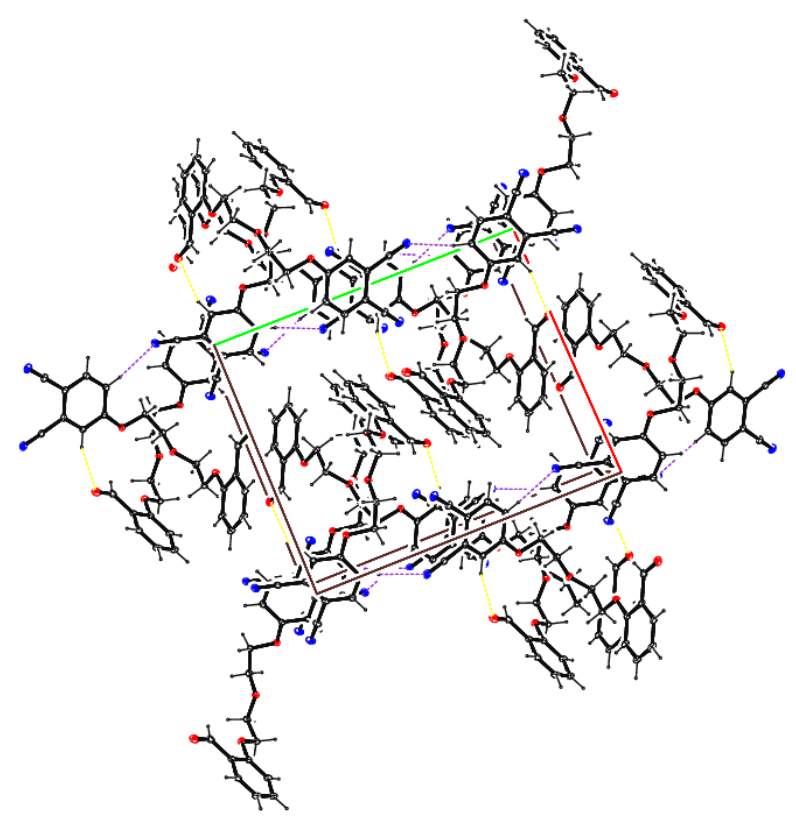

(b)

Figure 6. (a) Crystal-packing diagram of the title compound, $\mathrm{C}_{19} \mathrm{H}_{16} \mathrm{~N}_{2} \mathrm{O}_{4}$, along the c-axis. (b) In the crystal-packing diagram, hydrogen bonds are shown as dashed lines along with $\mathrm{C} 5-\mathrm{H} 5 \cdots \mathrm{N} 1$ (purple) and $\mathrm{C} 3-\mathrm{H} 3 \cdots \mathrm{O} 4$ (yellow).

The HOMO-LUMO energies are directly related to ionization potential and electron affinity. The energy and distribution of the HOMO-LUMO orbitals and difference between $\mathrm{E}_{\text {Hомо }} \mathrm{E}_{\mathrm{LUMO}}$ gap are an essential point of stability for the molecules. A molecule with a small gap is more polarized and known as soft molecule. HOMO-LUMO orbital distribution and bandgap values of a synthesized compound were calculated by theoretical methods gathered in gas and DMF phases (Fig.7).
An important point that the HOMO orbitals are mainly localized on the formylphenoxy, whereas the LUMO orbitals are distributed within the phthalonitrile groups of the molecule. This means that the formylphenoxy group in the molecule would be more easily attacked. Another point is that $\mathrm{E}_{\text {номо-E }} \mathrm{E}_{\text {Lumo }}$ bandgap $(0.15926 \mathrm{eV})$ in DMSO is smallest value in all studied phases, showing that the molecule in the DMSO solvent has a stronger electron donating ability.
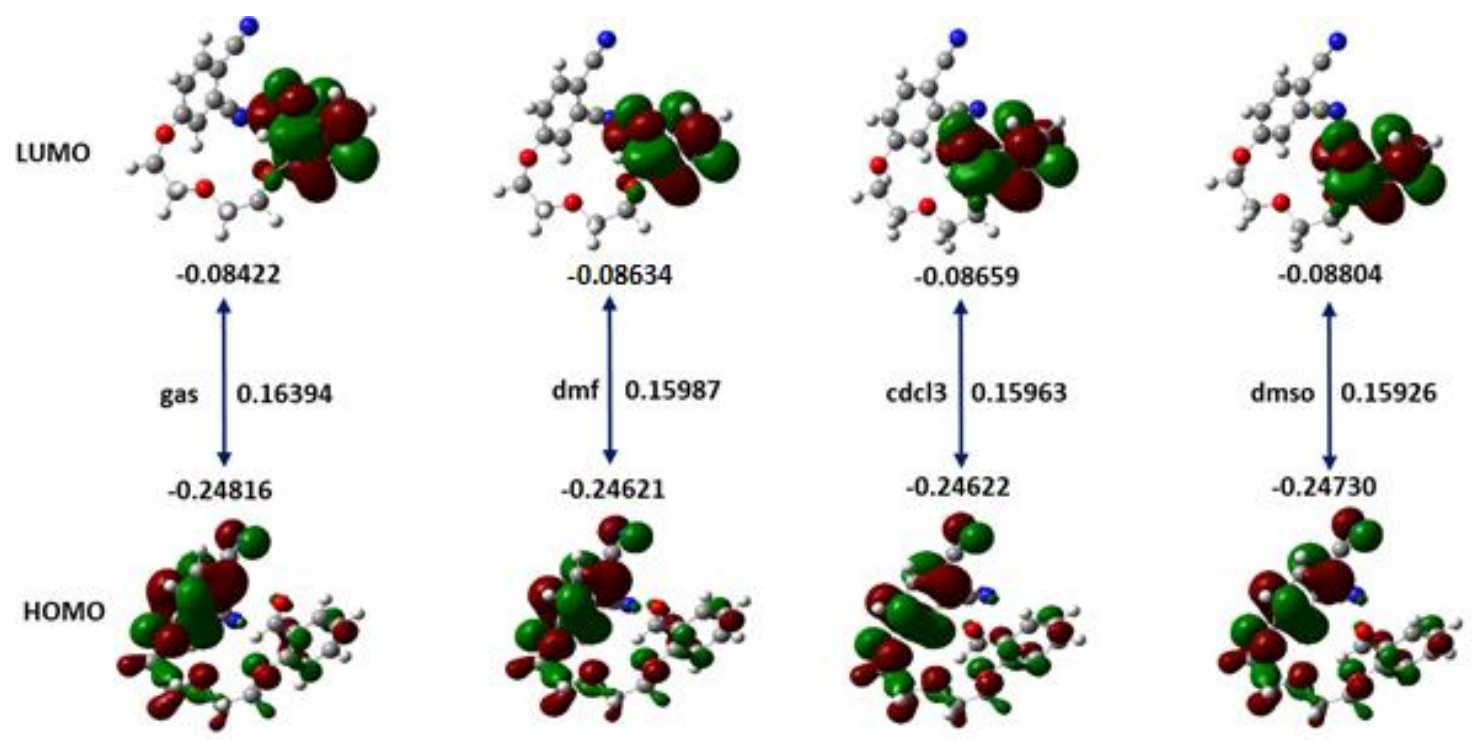

Figure 7. The HOMO-LUMO energies (eV) of the title molecule calculated by DFT/B3LYP/6-311+G(d,p) and bandgaps are in gas, DMF, DMSO and $\mathrm{CDCl}_{3}$ phases 
Molecular descriptor values obtained from the total energy for the title molecule in both gas and different solvents such as DMF, DMSO and $\mathrm{CDCl}_{3}$ are listed in Table 5. The hardness value $(\eta)$ is one-half the HOMO-LUMO gap of title molecule. Therefore, the larger the gap, the greater the hardness and thus stability of the title molecule. This property is therefore a powerful indicator that ultimately determines that hard molecules are less reactive than softer molecules. Table 5 shows that hardness is affected by solvent selectivity. In the gas phase and the phases of all of the studied solvents, the molecule has larger hardness value in when dissolved in DMSO. This finding is according to the greater hardness value of the molecule, indicating its greater stability. As hard molecules are less reactive than softer molecules [27], the stability order is therefore $\mathrm{DMSO}>\mathrm{CDCl}_{3}>\mathrm{DMF}>$ gas phase. A molecule with low chemical potential is a good electrophile, while an extremely hard molecule has feeble electron acceptability. Electrophilicity depends on both the chemical potential and the chemical hardness [28]. The calculated $\chi$ and $\omega$ values show that the more polar a solvent, the more it contributes to accentuate the parametric representation of activity. Additionally, we observed that solvent selection has a considerable effect on electrophile/nucleophile interactions.

\section{Table 5}

Molecular descriptors values of the title molecule calculated by DFT/B3LYP/6-311+G(d,p) level of theory

\begin{tabular}{lcccccccc}
\hline \hline \multicolumn{7}{c}{ Molecular descriptors } \\
\hline Solvent & \multirow{2}{*}{ Eномо } & \multirow{2}{*}{ E LUмо } & A & $\mathbf{I}$ & $\boldsymbol{\eta}$ & $\boldsymbol{\chi}$ & $\mathbf{\omega}$ & $\mathbf{S}$ \\
\hline Gas & -0.24816 & -0.08422 & 0.24816 & 0.08422 & -0.08197 & 0.16619 & -0.16847 & -6.09979 \\
DMF & -0.24621 & -0.08634 & 0.24621 & 0.08634 & -0.07994 & 0.16628 & -0.17294 & -6.25508 \\
DMSO & -0.24730 & -0.08804 & 0.24730 & 0.08804 & -0.07963 & 0.16767 & -0.17652 & -6.27904 \\
CDCL $_{3}$ & -0.24622 & -0.08659 & 0.24622 & 0.08659 & -0.07982 & 0.16641 & -0.17347 & -6.26449 \\
\hline \hline
\end{tabular}

\section{CONCLUSION}

In this work, 4-(2-(2-(2-formylphenoxy) ethoxy)ethoxy)phthalonitrile (compound 2) was synthesized and characterized by FT-IR, ${ }^{1} \mathrm{H}-\mathrm{NMR}$, ${ }^{13} \mathrm{C}-\mathrm{NMR}, \mathrm{UV}$-vis, MS, elemental analyses. This compound was obtained as single crystal, suitable for X-ray analysis. All crystallographic data agree with the theoretical bond lengths, angles, dihedral angles of compound 2 . The ${ }^{1} \mathrm{H}-\mathrm{NMR}$ and ${ }^{13} \mathrm{C}$ NMR results of the theoretical spectra agree with the experimental data. The value of the energy separation between the HOMO and LUMO provides important information about the title compound studied in gas, $\mathrm{CDCl}_{3}$ and DMSO. The Eномо-E $_{\text {LUMo }}$ bandgap $(0.15926 \mathrm{eV})$ in the DMSO is the smallest value in all studied phases, indicating that the molecule in DMSO solvent has stronger electron donating ability. Molecular descriptor values allow us to evaluate the molecule in terms of reactivity. These results imply that the molecule has larger hardness value in DMSO solvent, meaning that it is less reactive there than in any of the other studied solvents.
Acknowledgement. This work was supported by the Research Fund of Sakarya University (project no. 2014-02-04 007).

\section{REFERENCES}

[1] W. M Sharman, J. E. Lier, The Porphyrin Handbook, Academic Press, New York, 2003.

[2] T. M. Keller, T. K. Price, Amine-cured bisphenol-linked phthalonitrile resins, J. Macromol. Sci. Chem. 18, 931 (1982). DOI: https://doi.org/10.1080/00222338208077208

[3] S. Radhakrishnann, S. D. Deshpande, Conducting polymers functionalized with phthalocyanine as nitrogen dioxide sensors, Sensors, 2, 185-194 (2002). DOI: https://doi.org/10.3390/s20500185

[4] R. Bonnett, Chemical Aspects of Photodynamic Therapy, Gordon and Breach Science, Canada, 2000.

[5] M. Shimizu, L. Tauchi, T. Nakagaki, A. Ishikawa, E. Itoh, K. Ohta, Discotic liquid crystals of transition metal complexes 48: Synthesis of novel phthalocyanine-fullerene dyads and effect of a methoxy group on their clearing points, J. Porphyrins Phthalocyanines, 17, 264-282 (2013). DOI: https://doi.org/10.1142/S1088424613500752

[6] A. B. Sorokin, Phthalocyanine metal complexes in catalysis, Chem. Rev. 113, 8152 (2013). DOI: $10.1021 / \mathrm{cr} 4000072$

[7] G. Torre, P. Vazquez, F. Agullo-Lopez, T. Torres, Phthalocyanines and related compounds: organic targets 
for nonlinear optical applications, J. Mater. Chem. 8, 1671-1683 (1998). DOI: 10.1039/A803533D

[8] H. Kliesch, A. Weitemeyer, S. Miiller, D. Wohrle, Synthesis of phthalocyanines with one sulfonic acid, carboxylic acid, or amino group, Liebigs Ann. 12691273 (1995).

DOI: https://doi.org/10.1002/jlac.1995199507168

[9] P. Sen, S. Z. Yildiz, M. Tuna, M. Canlica, Preparation of aldehyde substituted phthalocyanines with improved yield and their use for Schiff base metal complex formation, J. Organomet. Chem., 769, 38-45 (2014). DOI: https://doi.org/10.1016/j.jorganchem.2014.07.007

[10] D. D. Perrin, W. L. F. Armarego, D. R. Perrin, Purification of Laboratory Chemicals, Pergamon Press, New York (2013).

[11] G. M. Sheldrick, A short history of SHELX, Acta Cryst. A, 64, 112 (2008). DOI: https://doi.org/10.1107/S0108767307043930

[12] G. M. Sheldrick, SHELXS97 and SHELXL97, University of Gottingen, Germany, 1997.

[13] G. M. Sheldrick, Crystal structure refinement with SHELXL, Acta Cryst. C, 71, 3-8. (2015). DOI: https://doi.org/10.1107/S2053229614024218

[14] C. F. Macrae, P. R. Edgington, P. McCabe, E. Pidcock, G. P. Shields, R. Taylor, M. Towler, J. Streek, Mercury: visualization and analysis of crystal structures, J. Appl. Cryst. 39, 453 (2006). DOI: https://doi.org/10.1107/S002188980600731X

[15] L. J. Farrugia, ORTEP-3 for Windows-a version of ORTEP-III with a Graphical User Interface (GUI), $J$. Appl. Cryst. 30, 565 (1997).

DOI: https://doi.org/10.1107/S0021889897003117

[16] L. Spek, Single-crystal structure validation with the program PLATON, J. Appl. Cryst. 36, 7 (2003). DOI: https://doi.org/10.1107/S0021889802022112

[17] (a) J. J. P. Stewart, Application of the PM6 method to modeling the solid state, J. Mol. Model, 14, 499-535 (2008). DOI: 10.1007/s00894-008-0299-7

(b) J. J. P. Stewart, Application of the PM6 method to modeling proteins, J. Mol. Model, 15, 765-805 (2009). DOI: $10.1007 / \mathrm{s} 00894-008-0420-\mathrm{y}$

[18] Spartan'16 Wavefunction, Inc. Irvine, CA.

[19] C. Lee, W. Yang, R. G. Parr, Development of the ColleSalvetti correlation-energy formula into a functional of the electron density, Phys. Rev. B, 37, 785 (1988). DOI: https://doi.org/10.1103/PhysRevB.37.785

[20] G Scalmani, M. J. Frisch, Continuous surface charge polarizable continuum models of salvation. I. General formalism, J. Chem. Phys. 132, 114110 (2010). DOI: https://doi.org/10.1063/1.3359469
[21] (a) F. London, Théorie quantique des courants interatomiques dans les combinaisons aromatiques, J. Phys. Radium, 8, 397-409 (1937).

DOI: 10.1051/jphysrad:01937008010039700;

(b) J. R. Cheeseman, G. W. Trucks, T. A. Keith, M. J. Frisch, A comparison of models for calculating nuclear magnetic resonance shielding tensors, J. Chem. Phys. 104, 5497-509 (1996). DOI: https://doi.org/10.1063/1.471789

[22] (a) R. G. Parr, R. G. Pearson, Absolute hardness: companion parameter to absolute electronegativity, $J$. Am. Chem. Soc. 105, 7512 (1983). DOI: 0002-7863/83/1505-7512\$01.50/0

(b) R.G. Pearson, Chemical hardness and bond dissociation energies, J. Am. Chem. Soc. 110, 7684 (1988). DOI: 0002-7863/88/1510-7684S01.50/0

[23] R. Dennington, T. Keith, J. Millam, GaussView, Version 5, Semichem Inc., Shawnee Mission KS, 2009.

[24] M. J. Frisch, G. W. Trucks, H. B. Schlegel, G. E. Scuseria, M. A. Robb, J. R. Cheeseman, J. A. Montgomery, J. T. Vreven, K. N. J. C. Kudin, J. M. Millam, S. S. Iyengar, J. Tomasi, V. Barone, B. Mennucci, M. Cossi, G. Scalmani, N. Rega, G. A. Petersson, H. Nakatsuji, M. Hada, M. Ehara, K. Toyota, R. Fukuda, J. Hasegawa, M. Ishida, T. Nakajima, Y. Honda, O. Kitao, H. Nakai, M. Klene, X. Li, J. E. Knox, H. P. Hratchian, J. B. Cross, C. Adamo, J. Jaramillo, R. Gomperts, R. E. Stratmann, O. Yazyev, A. J. Austin, R. Cammi, C. Pomelli, J. W. Ochterski, P. Y. Ayala, K. Morokuma, G. A. Voth, P. Salvador, J. J. Dannenberg, V. G. Zakrzewski, A. D. Daniels, O. Farkas, A. D. Rabuck, K. Raghavachari, J. V. Ortiz “Gaussian 09”, Gaussian, Inc., Pittsburgh PA, 2009.

[25] S. Wenger, Z. Asfari, J. Vicens, Synthesis of two calix[4]arenes constrained to a 1,3-alternate conformation by diaza-benzo crown ether bridging, Tetrahedron Lett. 35, 8369-8372 (1994). DOI: https://doi.org/10.1016/S0040-4039(00)74409-1

[26] P. Sen, G. Y. Atmaca, A. Erdogmus, S. D. Kanmazalp, N. Dege, S. Z. Yildiz, Peripherally tetra-benzimidazole unitssubstituted zinc(II) phthalocyanines: Synthesis, characterization and investigation of photophysical and photochemical properties, J. Lumin. 194, 123-130 (2018). DOI: https://doi.org/10.1016/j.jlumin.2017.10.022

[27] C. Fierro, A. B. Anderson, D. A. Scherson, Electron donor-acceptor properties of porphyrins, phthalocyanines, and related ring chelates: A molecular orbital approach, J. Phys. Chem. 92, 6902-6907 (1988). DOI: 0022-3654/88/2092-6902S01.50/0

[28] N. Islam, D. C. Ghosh, On the electrophilic character of molecules through its relation with electronegativity and chemical hardness, Int. J. Mol. Sci. 13, 2160-2175 (2012). DOI: https://doi.org/10.3390/ijms13022160 